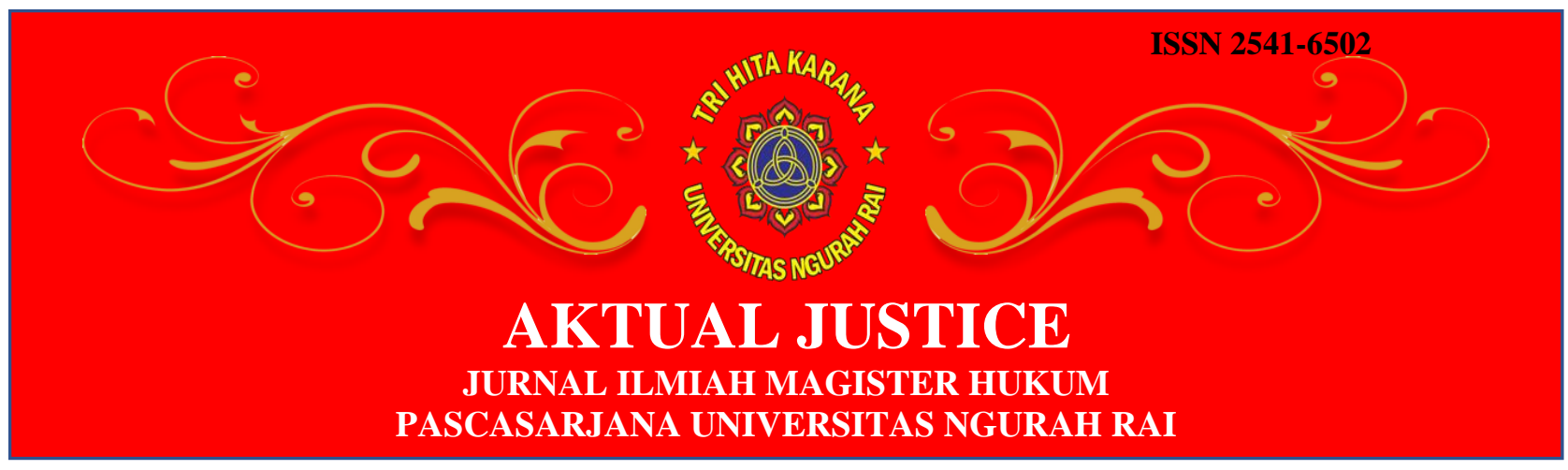

\title{
PENYIDIKAN POLRI TERHADAP TINDAK PIDANA KORUPSI DI DIREKTORAT RESERSE KRIMINAL KHUSUS POLDA BALI
}

\author{
T. Widodo Rahino
}

Polda Bali, email :

\begin{abstract}
This study used qualitative research methods to find the facts straight spaciousness to dig and explore the factors inhibiting what makes Directorate of Special Crime Investigation Bali Regional Police are not optimal in carrying out duties in handling the problem of corruption in Indonesia.

The findings of the study authors to submit a brief that the Directorate of Special Crime Investigation Bali Regional Police is not optimal in the performance of its duties in the handling of corruption. Many of the obstacles faced by the Directorate of Special Crime Investigation Bali Regional Police $\mathcal{E}$ Police like in terms of personnel, educational background, lack of technical instructions in the investigation regarding the handling of the Criminal Investigation Corruption, inadequate infrastructure, which is still very limited budget, going back and forth frequently the case, still merged the investigation at the Directorate of Special Crime Investigation Bali Regional Police Criminal Investigation Police makes no maximum results in performance of duties by personnel of Directorate of Special Crime Investigation Bali Regional Police. So the conclusion of this research is the Directorate of Special Crime Investigation Bali Regional Police is not optimal in performing law enforcement duties of corruption and other organizational structure recommendation two researchers present the comparison with the Attorney (Assistant Attorney General for Specific Criminal Crime Case) and its Corruption Eradication Commission and other supporting data to prove that the, Directorate of Special Crime Investigation Bali Regional Police in the hope of renewal and improvement of the organizational.
\end{abstract}

Keyword : Corruption, Polda Bali

\footnotetext{
Abstrak

Penelitian ini menggunakan pendekatan kualitatif dengan metode penelitian ini mencari fakta-fakta langsung kelapangan dengan menggali dan mendalami faktor-faktor penghambat apa yang membuat Direktorat Reserse Kriminal Khusus Polda Bali belum optimal dalam melaksanakan tugas dalam penanganan masalah tindak pidana korupsi di wilayah hokum Polda Bali.

Hasil temuan penelitian penulis menyampaikan secara ringkas bahwa Direktorat Reserse Kriminal Khusus Polda Bali belum optimal dalam pelaksanaan
} 
tugasnya dalam penanganan tindak pidana korupsi. Banyak hambatan-hambatan yang di hadapi oleh Direktorat Reserse Kriminal Khusus Polda Bali seperti dari segi personel, latar belakang pendidikan, belum adanya petunjuk teknis dalam penyidikan mengenai penanganan Tindak pidana korupsi dari Bareskrim, sarana prasarana yang belum memadai, anggaran yang masih sangat terbatas, sering terjadi bolak balik perkara, masih digabungnya penyelidikan dan penyidikan di Direktorat Reserse Kriminal Khusus Polda Bali sehingga membuat tidak maksimalnya hasil dalam pelaksanaan tugas oleh personel Direktorat Reserse Kriminal Khusus Polda Bali. Sehingga kesimpulan dari penelitian ini adalah Direktorat Reserse Kriminal Khusus Polda Bali belum optimal dalam melaksanakan tugas penegakkan hukum bidang korupsi dan rekomendasi 2 struktur organisasi lainnya peneliti sajikan yaitu perbandingan dengan Kejaksaan (Jaksa Agung Muda Tindak Pidana Khusus) dan Komisi Pemberantasan Korupsi beserta dan data-data pendukung lainnya untuk membuktikan bahwa Direktorat Reserse Kriminal Khusus Polda Bali belum optimal, dengan harapan adanya pembaharuan dan perbaikan struktur organisasi Direktorat Reserse Kriminal Khusus Polda Bali dan juga dibutuhkan pimpinan yang mempunyai komitmen untuk melawan para koruptor di Indonesia ini khususnya di wilayah hokum Polda Bali dalam rangka mendukung pelaksanaan tugas para personil Direktorat Reserse Kriminal Khusus Polda Bali.

Kata Kunci : Korupsi, Polda Bali

\section{Pendahuluan}

Korupsi yang tejadi di Indonesa sudah sangat memprihatinkan. Korupsi tidak hanya dilakukan oleh pegawai negeri, tetapi juga melibatkan pengusaha, swasta, pejabat negara, aparat penegak hukum serta para wakil rakyat yang duduk di DPR maupun DPRD. Korupsi merupakan extra ordinary crime (kejahatan luar biasa) dan untuk memberantasnya bukan perkara yang mudah, sehingga dibutuhkan cara yang luar biasa pula dengan dukungan dan komitmen seluruh rakyat Indonesia, aparat negara dan profesionalisme aparat penegak hukum yang tentunya juga harus didukung dengan penyempurnaan perangkat undang-undang yang terkait dengan pemberantasan korupsi khususnya penyidik POLRI.

Pengalaman empiris selama ini menunjukkan penyelidikan, penyidikan, dan penuntutam dalam peradilan tindak pidana korupsi memerlukan dukungan dan wewenang yang bersifat extra ordinary (luar 
biasa), profesional, dan dukungan biaya yang besar, serta tersedianya waktu untuk penyelidikan dan penyidikan yang cukup. ${ }^{1}$

Institusi pada tingkat pelaksanaan (aparat penegak hukum) yang diberi tugas dan tanggung jawab menanggulangi tindak pidana korupsi, memerlukan sarana berupa perangkat hukum yang memberikan landasan guna dapat melaksanakan tugas dan kewajiban secara efektif. Oleh karena itu, diperlukan istrumen yang luar biasa tersebut tidak bertentangan dengan atau menyimpang dengan berbagai standar yang berlaku secara universal. Instrumen hukum yang luar biasa yang diadopsi ke dalam hokum acara pidana, khususnya hukum acara dalam tindak pidana korupsi itu, antara lain, dapat berupa "pembalikan beban pembuktian". ${ }^{2}$

Upaya yang telah dilakukan pemerintah dalam memberantas korupsi dilakukan diantaranya dengan penyempurnaan Undang-undang tentang Pemberantasan Korupsi dan pembentukan lembaga pemberantasan korupsi baru guna mendukung penegakan hukum. Pemerintah telah membentuk Undang-undang Nomor 31 Tahun 1999 tentnag Pemberantasan Tindak Pidana Korupsi menggantikan Undangundang Nomor 31 Tahun 1971. Dua tahun kemudian untuk menyempurnakan Undang-undang Nomor 31 Tahun 1999, pemerintah mengeluarkan Undang-undang Nomor 20 Tahun 2001 tentang Perubahan Atas Undang-undang Nomor 31 tahun 1999 tentang Pemberantasan Tindak Pidana Korupsi.

Dikeluarkannya Undang-undang Nomor 20 Tahun 2001 salah satunya disebabkan oleh adanya berbagai interpretasi atau penafsiran yang berkembang dimasyarakat khususnya mengenai tindak pidana korupsi yang dilakukan sebelum diundangkannya undang-undang Nomor 31

${ }^{1}$ Mochtar, M.A. (2006). Memberantas Korupsi,Efektivitas Sistem Pembalikan Beban Pembuktian dalam Gratifikasi. Jakarta: Q-Communication, h.5.

2 Jaya, NSP. (2008). Beberapa Pemikiran Ke Arah pengembangan hukum Pidana. Bandung: PT Citra Aditya Bakti. h.58. 
Tahun 1999, karena Undang-undang ini menyebutkan bahwa sejak berlakunya Undang-undang Nomor 31 Tahun 1999 maka Undang-undang Nomor 3 Tahun 1971 tentang Pemberantasan Tindak Pidana Korupsi tidak berlaku lagi, sehingga timbul suatu anggapan adanya kekosongan hukum untuk memproses tindak pidana korupsi yang terjadi sebelum berlakunya Undang-undang Nomor 31 Tahun 1999.3

Selain melakukan penyempurnaan Undang-undang tentang Pemberantsan Korupsi, pemerintah juga membentuk lembaga pemberantasan korupsi baru, yaitu Komisi Pemberantasan Korupsi (KPK) melalui Undang-undang Nomor 30 Tahun 2002 tentang Komisi Pemberantasan Tindak Pidana Korupsi. Salah satu alasan dibentuk nya lembaga ini adalah pemberantasan korupsi belum optimal dan lembaga pemerintah yang menangani perkara korupsi (Kejaksaan dan Kepolisian) belum berfungsinya secara efektif dan efisien dalam memberantas korupsi. ${ }^{4}$

Dengan demikian, pembaharuan hukum pidana pada hakikatnya mengandung makna, suatu upaya untuk melakukan reorientasi dan reformasi hukum pidana yang sesuai dengan nilai-nilai sentral sosiopolitik, sosio filosofis, sosio kultural masyarakat Indonesia yang melandasi kebijakan kriminal dan kebijakan penegakan hukum di Indonesia. ${ }^{5}$

Pembaharuan hukum pidana harus dilakukan dengan pendekatan kebijakan, karena pada hakikatnya pembaharuan hukum yang dilakukan adalah bagian dari suatu langkah kebijakan (policy) yaitu bagian dari

3Indonesia, Undang-undang Tentang Perubahan Atas Undang-undang Nomor 31 Tahun 1999 Tentang Pemberantasan Tindak Pidana Korupsi, UU No.20, LN No.134 Tahun 2002, TLN No.4150, Penjelasan Umum

4Indonesia, undang-undang tentang Komisi Pemberantasan Tindak Pidana Korupsi, UU No.30, LN No.137 Tahun 2002, TLN 4250, bagian menimbag, huruf (a) dan (b).

${ }^{5}$ Arief, B.N. (1996). Bunga Rampai Kebijakan Hukum Pidana. Bandung : PT Citra Aditya Bakti. h. 31 
politik hukum atau penegakan hukum, politik hukum pidana, politik kriminal, dan politik sosial. Setiap kebijakan (policy) pertimbangan nilai. Oleh karena itu, pembaharuan hukum pidana harus pula berorientasi pada pendekatan nilai ${ }^{6}$.

Kebijakan pidana (penal policy), sebagaimana kebijakan publik umumnya, pada dasarnya harus merupakan kebijakan yang rasional. Kebijakan legislatif merupakan kebijakan dalam menetapkan merumuskan sesuatu di dalam peraturan perundang-undangan oleh karena itu sering juga kebijakan legislatif disebut sebagai istilah kebijakan formulatif?. Kebijakan formulasi merupakan tahap paling strategis dari keseluruhan proses operasionalisasi atau fungsionalisasi dan konkretisasi hukum pidana dalam rangka penanganan korupsi di Indonesia.

\section{Metode Penelitian}

Penelitian ini merupakan penelitian deskriptif kualitatif dengan telaah teori berdasarkan kajian pustaka dan penelitian yang relevan. Kajian pustaka memiliki peranan penting dalam penelitian, yakni untuk mendasari dan memperkokoh gagasan peneliti. Idealnya, literatur yang dikaji merupakan sumber asli dari artikel maupun jurnal ilmiah ${ }^{8}$.

\section{Hasil Dan Pembahasan}

\section{a. Tugas dan Wewenang Polri}

Kepolisian dalam UU No. 2 Tahun 2002 Tentang Kepolisian diartikan sebagai segala hal-ihwal yang berkaitan dengan fungsi dan lembaga polisi sesuai dengan peraturan perundang-undangan. Anggota

8 Sugiyono. (2015). Metodologi Penelitian. Bandung: Alfabeta. h.113. 
Kepolisian Negara Republik Indonesia adalah pegawai negeri pada Kepolisian Negara Republik Indonesia sedangkan Pejabat Kepolisian Negara adalah anggota Kepolisian Negara Republik Indonesia yang berdasarkan undang-undang memiliki wewenang umum kepolisian. Peraturan kepolisian adalah segala peraturan yang dikeluarkan oleh Kepolisian Negara Republik Indonesia dalam rangka memelihara ketertiban dan menjamin keamanan umum sesuai dengan peraturan perundang-undangan.

\section{Kekuasaan Kepolisian dalam Institusi Polisi Modern}

Norma hukum memiliki tugas sangat penting yakni untuk menjaga kedamaian hidup bersama. Kedamaian hidup bersama berarti di dalam masyarakat terdapat ketertiban atau keamanan dan ketentraman atau ketenangan. Berbeda dengan norma-norma lainnya terdapat kemungkinan bagi norm hukum untuk dipaksakan kepada tiap individu dalam masyarakat oleh suatu otoritas bahwa norma hukum ini memiliki daya ikat bagi tiap individu; serta kemungkinan untuk dijatuhkannya sanksi bagi individu yang melakukan perbuatan yang bertentangan dengan norma hukum.

Tugas untuk mengawasi dan memelihara agar norma-norma hukum (undang-undang) tersebut terpelihara dengan baik dalam masyarakatmerupakan tugas utama yang diemban oleh lembaga kepolisian. Dengan demikian kita dapat melihat bahwa terjadi suatu pengkhususan dari fungsi yang semula meliputi semua bidang kenegaraan menjadi fungsi yang khusus memelihara keamanan dan ketertiban di dalam masyarakat. Sifat dari tugas polisi adalah: ${ }^{9}$ Preventif (sifat mencegah), yaitu menjaga jangan sampai terjadi perbuatan atau kelalaian yang dapat mengganggu ketertiban dan keamanan. Represif (sifat 
memberantas) yaitu mencari dan menyelidiki peristiwa-peristiwa yang telah mengganggu ketertiban dan keamanan. Disebut juga justitionele atau rechterlijke taak der politie karena berhubungan dengan pengadilan.

2. Asas-asas dalam Pelaksanaan Tugas dan Wewenang Kepolisian.

Pelaksanaan wewenang kepolisian didasarkan pada tiga asasyakni: asas legalitas, asas plichmatigheid, asas subsidiaritas Asas legalitas adalah asas di mana setiap tindakan polisi harus didasarkan kepada undangundang/ peraturan perundang-undangan. Bilamana tidak didasarkan kepada undang-undang/ peraturan perundang-undangan maka dikatakan bahwa tindakan polisi itu melawan hukum (onrechtmatig).

3. Tugas dan Wewenang Polri Menurut Undang-Undang Kepolisian

Undang-undang Kepolisian menyebutkan bahwa tugas pokok kepolisian Negara Repubik Indonesia adalah: ${ }^{10}$ Memelihara keamanan dan ketertiban masyarakat; Menegakkan hukum; dan Memberikan perlindungan, pengayoman, dan pelayanan kepada masyarakat. Penjelasan dari pasal 13 tersebut menyebutkan bahwa rumusan pasal tersebut tidak didasarkan pada suatu urutan prioritas, artinya ketigatiganya sama penting. Dalam pelaksanaannya pun tugas pokok yang akan dikedepankan sangat tergantung pada situasi masyarakat dan lingkungan yang dihadapi karena pada dasarnya ketiga tugas pokok tersebut dilaksanakan secara simultan dan dapat dikombinasikan. Dalam Undangundang kepolisian, keamanan dan ketertiban masyarakat diartikan sebagai : "suatu kondisi dinamis masyarakat sebagai salah satu prasyarat terselenggaranya proses pembangunan nasional dalam rangka tercapainya tujuan nasional yang ditandai oleh terjaminnya keamanan, ketertiban, dan tegaknya hukum, serta terbinanya ketentraman, yang mengandung kemampuan membina serta mengembangkan potensi dan kekuatan

10UU Kepolisian, Pasal 13 
masyarakat dalam menangkal, mencegah, dan menanggulangisegala bentuk-bentuk gangguan lainnya yang dapat meresahkan masyarakat."11 b. Tindakan Penyidik/Polri Dalam Proses Penyidikan Terhadap Tindak Pidana Korupsi Di Wilayah Hukum Direktorat Resesrse Kriminal Khusus Polda Bali saat ini

Menurut pasal 1 angka $1 \mathrm{KUHAP}$, penyidk adalah pejabat polisi negara Republik Indonesia atau pegawai negeri sipil tertentu yang diberi wewenang khusus oleh undang-undang untuk melakukan penyidikan. Sedangkan pada pasal 1 angka 4 menyebutkan bahwa penyelidik adalah pejabat polisi negara Republik Indonesia yang diberi wewenang oleh undang-undang ini untuk melakukan penyelidikan. Jadi perbedaannya ialah penyidik terdiri dari polisi negara danpegawai negeri sipil tertentu yang diberi wewenang khusus oleh undang-undang, sedangkan penyelidik hanya terdiri dari polisi negara saja. Dalam pasal 6 KUHAP ditentukan dua badan yang dibebani wewenang penyelidikan, yaitu: Pejabat Polisi Negara Republik Indonesia. Pejabat Pegawai Negeri Sipil tertentu yang diberi wewenang khusus oleh undang-undang. Khusus untuk tindak pidana korupsi, institusi yang diberi wewenang untuk melakukan penyidikan adalah:

a. Kejaksaan (Jaksa)

Sejak diundangkannya KUHAP, kewenangan jaksa dalam melakukan penyidikan tindak pidana korupsi menjadi kontroversi di kalangan masyarakat dan dunia peradilan. Ada yang berpendapat bahwa jaksa tidak berwenang lagi melakukan penyidikan, namun ada yang berpendapat bahwa jaksa masih berwenang melakukan penyidikan. Sesuai dengan ketentuan pasal 284 ayat (2) KUHAP disebutkan bahwa dalam waktu dua tahun sejak KUHAP diundangkan, maka terhadap semua

11Pasal 1 butir 5 
perkara diberlakukan ketentuan KUHAP, kecuali mengenai ketentuan khusus acara pidana sebagaimana yang diatur dalam undang-undang tertentu untuk sementara tetap berlaku sampai aa perubahan dan/atau dinyatakan tidak berlaku lagi. Dalam penjelasan pasal ini disebutkan bahwa yang dimaksud dengan ketentuan khsus tentang acara pidana sebagaimana tersebut pada undang-undang tertentu adalah ketentuan khsus acara pidanasebagaimana tersebut pada: Undang-undang tentang Pengusutan, penuntutan dan peradilan Tindak Pidana Ekonomi (UU No. 7 Darurat Tahun 1951) Undang- undang tentang Pemberantasan Tindak Pidana Korupsi (UU No. 3 Tahun 1971)

b. Kepolisian Negara Republik Indonesia

Berdasarkan Undang-undang Nomor 2 Tahun 2002 tentang Kepolisian Negara Republik Indonesia, dalam pasal 14 huruf g disebutkan bahwa : "Kepolisian Negara Republik Indonesia bertugas melakukan penyelidikan dan penyidikan terhadap semua tindak pidana sesuai dengan hukum acara pidana dan peraturan perundang-undangan lainnya". Dari ketentuan ini, Kepolisian berwenang melakukan penyidikan tindak pidana korupsi, karena Kepolisian Negara RI berwenang melakukan penyelidikan dan penyidikan terhadap semua tindak pidana, termasuk tindak pidana korupsi.

c. Komisi Pemberantasan Tindak Korupsi

Transparency International (TI) dalam penelitiannya tahun 1998-2003, Indonesia menempati posisi 10 besar negara paling korup di dunia. Demikian pula Political and Economic Risk Consultancy (PERC) dalam penelitiannya tahun 1997 mengemukaakn bahwa Indonesia menempati posisi negara yang terkorup di Asia, dan pada tahun 2001, Indonesia turun peringkat menjadi negara terkorup ke-2 di Asia setelah Vietnam. Bahkan menurut Corruption Perception Index (CPI) tahun 2006 yang dirilis Transparency International Indonesia (TII) November 2006, Indonesia berada 
pada peringkat ke-7 negara terkorup dari 163 negara. Vice President East Asia and Pacific Region of The world Bank telah memasukkan daftar hitam kepada 306 prusahaan di seluruh dunia karena adanya indikasi korupsi dana bantuan lembaga donor international da 65 perusahaan diantaranya adalah perusahaan Indonesia. Dalam kurun waktu 2006-2006 tercatat 100 kasus adanya indikasi korupsi dana bantuan Bank Dunia. Menurut laporan Bureaucratic and Judiciary Bribery 1998, kasus korupsi dalam bentuk penyuapan yang terjadi di lembaga peradilan di Indonesia paling tinggi diantara negara-negara seperti Ukraina, Venezuela, Kolombia, Mesir, dan Turki. Hal yang sama dapat dijumpai dari hasil penelitian yang dilakukan oleh Indoneisa Corruption Watch tahu 2001 dan survei nasional tentang korupsi Partnership for Governance Reform tahun 2002. Mengenai praktik korupsi yang terjadi di lembaga peradilan, dikenal dengan istilah “judicial corruption" dan sudah sangat popular di kalagan masyarakat.

Harapan lain adalah bahwa KPK harus menjadi landasan yang kuat secara substantif maupun inplemntatif sehingga merupakan salah satu institusi yang mampu mengemban misi penegakan hukum. Dalam mengemban misi tersebut, KPK mendapat tugas dan wewenang yang cukup luas dengan menganut prinsip-prinsip: (i) kepasatian hukum, (ii) keterbukaan, (iii) akuntabilitas, (iv) kepentingan umum, dan (v) proporsionalitas (Pasal 5 UU-KPK). Mengenai tugas dari KPK, pasal 6 UU-KPK menyebutkan:

1). Koordinasi dengan instansi yang berwenang melakukan pemberan tasan tindak pidana korupsi;

2). Supervisi terhadap instansi yang berwenang melakukan pemberan tasan tindak pidana korupsi;

3). Melakukan penyelidikan, penyidikan, dan penuntutan terhadap tindak pidana korupsi;

4). Melakukan tindakan-tindakan pencegahan tindak pidana korupsi;

5). Melakukan monitor tehadap penyelenggaraan pemerintahan negara. 
Sedangkan wewenang dari KPK dalam rangka pemberantasan korupsi dinyatakan dalam pasal 7 Undang-Undang KPK sebagai berikut:

1). Mengordinasian penyelidikan, penyidikan dan enuntutan tindak pidana korupsi;

2). Menetapkan system pelaporan dalam kegiatan pemberantasan tindak pidana korupsi;

3). Meminta informasi tentang kegiatan pemberantasan tindak pidana korupsi kepada instansi lain yang terkait;

4). Melaksanakan dengar pendapat atau pertemuan dengan instansi yang berwenang malakukan pemberantasan tindak pidana korupsi;

5). Meminta laporan instansi terkait mengenai pencegahan tindak pidana korupsi.

Kewenangan lain yang lebih luas dari KPK adalah mengambil alih wewenang penyidikan dan penuntutan dari pihak Kepolisian atau Kejaksaan dengan prinsip "trigger mechanism" dan "take over mechanism" (pasal 8 dan 10 UU-KPK). Pengambil alihan wewenang ini dapat dilakukan jiga terdapat indikasi "unwillingness' dari institusi terkait dalam menjalankan tugas dan wewenangnya. Indikasi adanya "unwillingness" diatas berdasarkan pada pasal 9 UU-KPK, yaitu: (i) adanya laporan masyarakat mengenai tindak pidana korupsi yang tidak ditindaklanjuti, (ii) proses penanganan tindak pidana korupsi yang berlarut-larut, (iii) adanya unsure nepotisme yang melindungi pelaku korupsi, (iv) adanya campur tangan pihak eksekutuf, legislative dan yudikatif, (v) alasan-alasan lain yang menyebabkan penaganan tindak pidana korupsi sulit dilaksanakan.

d. Penyelidikan dan Penyidikan

Istilah penyelidikan dan penyidikan dipisahkan artinya oleh KUHAP, walaupun menurut bahasa Indonesia kedua kata itu berasal dari 
kata dasar sidik, yang artinya memeriksa, meneliti. ${ }^{12}$ Dalam mengungkap suatu tindak pidana tidak terlepas dari upaya penyelidikan dan penyidikan, dimana penyelidikan adalah serangkaian tindakan penyelidik untuk mencari dan menemukan suatu peristiwa yang diduga sebagai tindak pidana guna menentukan dapat atau tidaknya dilakukan penyidikan menurut cara yang diatur dengan undang-undang. Sedangkan penyidikan adalah serangkaian tindakan penyidik dalam hal dan menurut cara yang diatur menurut undang-undang untuk mencari serta mengumpulkan barangbukti yang dengan bukti itu membuat terang tindak pidana yang terjadi dan guna menemukan tersangkanya.

Penyelidikan merupakan tindakan-tindakan yang mengawali penyidikan untuk menentukan suatu peristiwa itu termasuk tindak pidana. Apabila sudah ditentukan bahwa peristiwa tersebut adalah tindak pidana, maka sasaran penyidikan adalah mengumpulkan bukti-bukti guna membuat terang tindak pidana tersebut dan menemukan tersangkanya. Menurut pasal 7 KUHAP.

\section{c. Mekanisme penanganan tindak pidana korupsi oleh Penyidik Direktorat Reserse Kriminal Khusus Polda Bali.}

Adapun dalam penanganan Tindak Pidana Korupsi oleh Penyidik Polri yang dalam hal ini dilakukan oleh Penyidik Direktorat Reserse Kriminal Khusus Polda Bali adalah dengan strategi penanganan sebagai berikut:

a. Sumber Laporan kasus dan penanganannya.

Laporan tertulis dari Lembaga Swadaya Masyarakat (LSM), masyarakat, atau bahkan surat anonim,

b. Penyidikan, dengan telah dibuatnya Laporan Polisi maka segera proses penyidikan dimulai dengan :

${ }^{12}$ Hamzah, A. (2004). Hukum Acara Pidana. cet. 3. Jakarta: Sinar Grafika. h.117. 
1). Terbitkan Surat Perintah Penyidikan dan ditunjuk anggota atau penyidik yang betul-betul menguasai tentang seluk beluk perundang-undangan tindak pidana korupsi.

2) Siapkan data naskah yang didalamnya berisi:

- Rencana kegiatan penyidikan

- Proses Penyidikan Perkara

- Surat menyurat yang berkaitan dengan kasus yang ditangani.

- Berita Acara Pemeriksaan, Dll.

3). Pemeriksaan, pemeriksaan kepada Kepala Daerah/ DPRD danNotaris sesuai dengan peraturan Perundang-undangan bahwa asas persamaan hak dimuka hukum tidak berlaku bagi orang-orang tertentu karena harus adanya ijin seperti: Pemeriksaan terhadap Kepala Daerah baik Gubernur/ Wakil Gubernur dan Bupati/ Wakil Bupati maupun walikota sesuai dengan Pasal 36 UU No. 32 tahun 2004 tentang Pemerintahan Daerah harus ada ijin tertulis dari presiden. Adapun tata cara pengajuannya : Dari Kapolresta/Kapolres diajukan kepada Kapolda Up Dir. Reskrimsus dengan dilampiri :

- Laporan polisi

- Surat Perintah Penyidikan

- Resume/ lapju singkat dan harus sudah bias menyebutkan adanya kerugian negara.

- Gelar perkara guna menentukan layak atau tidaknya permintaan ijin tersebut dilanjutkan, bila sudah lengkap ijin akan dilanjuti di Mabes Polri yang kemudian oleh Mabes Polri akan dilanjutkan ke Sekretariat Kabinet.

4). Pemeriksaan terhadap Ketua/ Aggota DPRD provinsi berdasarkanPasal 53 ayat (1) UU No. 32 Tahun 2004 tentang 
Pemerintah Daerah, pemeriksaan bias dilaksanakan bila sudah ada ijin tertulis dari Mendagri dan cara pengajuannya adalah berdasarkan Surat Dir III \& WCC tanggal 8 Februari 2006 tentang Ijin bias langsung ditandatangan oleh Kapolda dan ditujukan keMendagri, Persyaratannya adalah :

- Laporan Polisi

- Surat Perintah Penyidikan

- Laporan Kemajuan

- Gelar Perkara

5). Pemeriksaan terhadap Notaris sesuai Pasal 66 ayat (1) huruf b Undang-Undang Nomor 30 tahun 2004 tentang Jabatan Notaris harus ada persetujuan majelis pengawas daerah, Persayaratannya: Permintaan langsung diajukan oleh Kapolresta/ Kapolres Lampirannya adalah : Resumesingkat/ kronologis kasus posisi perkara yang ada kaitannya dengan Notaris tersebut.

6). Pemberkasan, didalam pemberkasan harus benar, rapi, urut, dan lengkap.

7). Penyelesaian Berkas perkara

8). Penyerahan Berkas Perkara Tahap I (satu), kepada Kejaksaan Tinggi untuk dilakukan penelitian oleh Jaksa Penuntut Umum

9). Penyerahan Berkas PerkaraTahap II (dua), yakni penyerahan tersangka dan Barang bukti kepada Kejaksaan Tinggi.

Melihat kompleksitas permasalahan korupsi di Indonesia, maka dalam rangka meningkatkan kemampuan penyidikan kasus korupsi tersebut oleh POLRI, telah dilaksanakan secara komprehensif dan simultan, dengan langkah-langkah: Arah kebijakan, sesuai paradigma baru Polri lebih mengedepankan aspek pelayanan, perlindungan dan pengayoman masya rakat dimana upaya penegakan hukum dilakukan 
sebagai sarana untuk mewujudkan Kamtibmas, maka arah kebijakan POLRI dalam memberantas tindak pidana korupsi, antara lain adalah:

a. Kegiatan penegakan hukum oleh POLRI, dimaksudkan untuk dapat memberi efek jera bagi pelaku dan calon pelaku;

b. Penyidikan kasus korupsi, disamping untuk membuktikan perbuatan pelaku, juga untuk semaksimal mungkin dapat mengembalikan kerugian keuangan negara;

c. Adanya pertimbangan tingkat penyidikan tindak pidana korupsi, misalnya : kasus yang melibatkan Bupati ditangani oleh Polwil atau Polda.

d. Untuk menghindari keluar masuknnya berkas perkara kasus korupsi, maka sejak awal penyidikan sudah dilakukan koordinasi dan komunikasi dengan Jaksa Peneliti;

e. Mengintensifkan koordinasi dan komunikasi dengan instansi terkait untuk mengoptimalkan penyidikan kasus korupsi;

f. Meningkatkan kredibilitas anggota/ Penyidik.

\section{Kesimpulan}

Sebagaimana telah dijelaskan bahwa kualitas Penyidik Direktorat Reserse Kriminal Khusus Polda Bali berkaitan dengan pengungkapan Tindak Pidana Korupsi masih tergolong rendah. Rendahnya kualitas diketahui berdasarkan indikator-indikator sebagai berikut :

a. Kondisi proses penyidikan tindak pidana korupsi dilakukan oleh Direktorat Reserse Kriminal Khusus Polda Bali saat ini masih belum efektif dan optimal.

b. Kondisi Penguasaan Undang-Undang Korupsi yang dikuasai oleh penyidik dan penyidik pembantu Dit III Pidkor \& WCC Bareskrim Polri masih sangat lemah sehingga penerapan pasal dan perundangundangan menjadi kurang tepat. 
c. Kondisi Sarana, Prasarana dan Anggaran yang dimiliki oleh masih terbatas dalam rangka menopang kegiatan penyelidikan dan penyidikan perkara korupsi perbankan.

d. Kondisi koordinasi antara penyidik Direktorat Reserse Kriminal Khusus Polda Bali dengan instansi lain seperti Bank Indonesia, Badan Pemeriksa Keuangan, Badan Pengawas Keuangan dan Pembangunan, serta lembaga Criminal Justice system seperti jaksa penuntut umum dan pengadilan masih lemah.

Menyadari realita demikian, Direktorat Reserse Kriminal Khusus Polda Bali berupaya agar penyidik lebih berkualitas sehingga mampu memuaskan pelanggan (masyarakat).

Berkaitan dengan semakin meningkatnya tindak pidana korupsi di Negara kita, dimana dari tahun ke tahun cenderung mengalami peningkatan (Crime Total) seperti terlihat dari perkara yang ditangani oleh Direktorat Reserse Kriminal Khusus Polda Bali, belum lagi perkara korupsi perbankan yang tidak terdeteksi dan terungkap karena kekurangtahuan permasalahan tindak pidana korupsi dan perbankan yang dimiliki oleh penyidik.

Disisi lain upaya penyelesaian kasus (Crime Clearence) yang ditangani Direktorat Reserse Kriminal Khusus Polda Bali menunjukkan kondisi yang belum memuaskan, maka guna menyikapi hal demikian, perlu diformulasikan suatu kebijaksanaan untuk meningkatkan kualitas penyidik Direktorat Reserse Kriminal Khusus Polda Bali

\section{DAFTAR PUSTAKA}

Arief, B.N. (1996). Bunga Rampai Kebijakan Hukum Pidana. Bandung : PT Citra Aditya Bakti.

Hamzah, A. (2004). Hukum Acara Pidana. cet. 3. Jakarta: Sinar Grafika. 
ISSN : 2541-6502

Jaya, NSP. (2008). Beberapa Pemikiran Ke Arah pengembangan hukum Pidana. Bandung: PT Citra Aditya Bakti.

Mochtar, M.A. (2006). Memberantas Korupsi,Efektivitas Sistem Pembalikan Beban Pembuktian dalam Gratifikasi. Jakarta: Q-Communication

Sugiyono. (2015). Metodologi Penelitian. Bandung: Alfabeta. 